\title{
MENDEKATKAN PEMUDA KE DAUR ULANG SAMPAH MAKANAN
}

\author{
Septin Puji Astuti ${ }^{1,2}$, Nurwulan Purnasari ${ }^{2}$ Purwono $^{2}$, Ardhi Ristiawan ${ }^{2}$ Annida Unatiq Ulya ${ }^{2}$ \\ 1. Jurusan Manajemen Bisnis Syariah, IAIN Surakarta, Indonesia \\ 2. Centre for Science and Technology, IAIN Surakarta, Indonesia
}

\begin{abstract}
Pemuda adalah penggerak perubahan sosial. Artikel ini akan menganalisis hasil pengabdian masyarakat yang dilakukan ke pemuda untuk mempromosikan daur ulang sampah rumah tangga. Daur ulang sampah makanan menjadi fokus dalam kegiatan pengabdian kepada masyarakat ini karena banyak masyarakat yang masih belum sadar bahwa sampah makanan juga sangat penting untuk diperhatikan. Tiga topik utama yang akan diberikan dalam pengabdian masyarakat ini adalah daur ulang sampah makanan dengan composting, mengolah sampah makanan menjadi makanan binatang, menggunakan sisa bahan makanan untuk mengolah kembali menjadi kue. Topik-topik tersebut disampaikan ke pemuda untuk meningkatkan pengetahuan pemuda akan daur ulang sampah rumah tangga. Hasil dari pengabdian kepada masyarakat ini sesuai dengan tujuan dari kegiatan pengabdian masyarakat, yaitu meingkatkan pengetahuan pemuda akan daur ulang sampah sehingga dapat merangsang keinginan pemuda untuk memulai gerakan daur ulang sampah di masyarakat. Mereka juga punya keinginan untuk menyampaikan kembali materi daur ulang sampah yang disampaikan dalam program pengabdian kepada masyarakat ke pada masyarakat di sekitar mereka tinggal. Akan tetapi, kenaikan pengetahuan mereka tidak menaikkan keoptimisan mereka dalam melakukan daur ulang sampah. Beberapa di antara mereka masih skeptis pada kegiatan daur ulang sampah makanan akan berhasil diterapkan di masyarakat.
\end{abstract}

Kata Kunci: Sampah makanan; pemuda; daur ulang; minat daur ulang

\section{PENDAHULUAN}

Sampah makanan, termasuk bahan makanan dan makanan yang sudah dimasak adalah bahan makanan yang dibuang atau yang tidak digunakan (USEPA, 2012). Di dunia, sampah makanan merupakan salah satu masalah yang harus dicarikan solusinya (Iacovidou et al., 2012). Sampah makanan sangat penting untuk diatasi karena rantai makanan akan menghasilkan greenhouse gasses (GHGs). Nitrogen Oksida $\left(\mathrm{N}_{2} \mathrm{O}\right)$ dari tanah dan proses pertanian, metana $\left(\mathrm{CH}_{4}\right)$ dari sampah makanan, dan emisi karbon dioksida $\left(\mathrm{CO}_{2}\right)$ yang dihasilkan dari proses memasak makanan dan transportasinya adalah contoh-contoh GHGs yang dihasilkan dari rantai makanan (Dorward, 2012). Selama proses pengumpulan dan transportasinya, sampah makanan menimbulkan bau, pembusukan, dan sumber lindi karena kandungan zat padat yang tinggi volatilitasnya yang merupakan beban lingkungan (Han \& Shin, 2004). Selain itu, sampah makanan mempegaruhi biaya (Xu et al., 2018). Dukungan finansial selama mengatasi sampah dan aktifitas untuk mengurangi dampak kesehatan, lingkungan dan sosial sangat diperlukan juga.

Indonesia bersama dengan India dan Amerika Serikat adalah penghasil sampah makanan terbesar kedua di dunia (The Economist, 2016). Hasil studi menemukan bahwa masyarakat Indonesia membuang sampah makanan 300 kilogram makanan per orang per tahun. Kondisi ini tentu harus segera diatasi.
Beberapa upaya telah dilakukan, untuk mengatasi sampah makanan. Mengubah pengelolaan sampah makanan dari teknologi landfill ke teknologi yang lebih modern akan mencegah sampah padat makanan, mencegah emisi GHG dan sekaligus emisi gas dari sampah makanan dapat dimanfaatkan sebagai sumber energi baru terbarukan (Franchetti, 2013). Selain itu ada daur ulang menjadi solusi atas peningkatan konsumsi. Namun, daur ulang bagi sebagian saintis tidak begitu diminati karena daur ulang membutuhkan energi selama prosesnya (Bekin, 2007). Meski begitu, daur ulang bisa jadi alternatif untuk mencegah keurusakan lingkungan akibat over consumption. Beberapa penelitian telah membuktikan bahwa perilaku mendaur ulang dapat meningkatkan kesadaran lingkungan yang nanti akan berdampak pada penurunan produksi sampah makanan (Abdelradi, 2018).

Di Eropa, sampah makanan dipertimbangkan dalam kebijakan lingkungan karena banyaknya jumlah sampah makanan yang dibuang di sana (Monier et al., 2010). Gustavsson et al. (2013) melaporkan 1,3 juta makanan per tahun di Eropa. Enviromental Protection Agency (EPA) Amerika juga melaporkan bahwa sampah makanan memberi kontribusi besar pada jumlah sampah yang dibuang di tempat pembuangan sampah. Sampah makanan di tempat pembuangan sampah lebih dari $95 \%$. Sampah itu bisa berubah menjadi karbon dioksida, metana, dan gas rumah kaca (GHG) lainnya. Kurangnya manajemen sampah di desa mendorong orang membuang sampah sembarangan seperti di sungai. 
Salah satu penyelesaian yang sudah ditawarkan di beberapa tempat adalah mempromosikan home composting daripada melakukan composting tersentralisasi di tempat pembuangan sampah (Lundie \& Peters, 2005). Di Indonesia hal ini juga sudah banyak dipromosikan. Selain itu, daur ulang sampah makanan dan kemasan bekas makanan juga banyak dikenalkan. Hal ini karena kegiatan daur ulang sampah makanan dan kemasannya memiliki dampak yang baik terhadap pengurangan sampah mkanan (Irani et al., 2017).

\section{IDENTIFIKASI MASALAH}

Berbagai studi telah melakukan identifikasi bahwa komposisi sampah makanan dihasilkan dari sayuran, roti, makanan ringan, daging, buah, dan susu (Lebersorger \& Schneider, 2011; Reutter et al., 2017). Sampah dari kemasan makanan banyak diproduksi dari kemasan saus, teh dan minuman (Lebersorger \& Schneider, 2011).

Selama ini sudah banyak seminar dan konferensi gratis yang diberikan kepada masyarakat untuk menarik perhatian masyarakat dalam melakukan kegiatan daur ulang sampah domestik. Berdasarkan hasil observasi lapangan, ada tiga masalah yang diidentifikasi sehingga memunculkan kegiatan ini. Ketiga masalah tersebut adalah kurangnya pengelolaan persampahan terutama di desa, kurangnya kegiatan mendaur ulang sampah makanan, dan dibutuhkan agen perubahan sosial dalam melakukan kegiatan pengelolaan dan daur ulang sampah.

\section{Pengelolaan sampah di desa}

Sampah makanan merupakan salah satu masalah di Indonesia, terutama di daerah perkotaan. Sampah makanan dipicu oleh kegiatan konsumsi. Di negara berkembang kurangnya teknik penyimpanan dan pendinginan makanan, kurangnya modernnya teknik memanen, kondisi iklim yang tidak diinginkan, kurangnya infrastruktur dan sistem pemasaran adalah penyebab timbulnya sampah makanan (FAO, 2012; Lang \& Rayner, 2012). Sampah makanan yang dihasilkan dari makanan yang sudah kadaluarsa, kelebihan konsumsi, dan pembelian banyak produk-produk yang mudah busuk juga merupakan sumber-sumber dari munculkan sampah makanan.

Berbeda dengan massyarakat di kota, masyarakat di desa cenderung lebih sedikit memproduksi sampah makanan karena sebagain besar dari mereka makan di rumah, tidak suka membeli makanan di luar (Mattar et al., 2018). Produksi sampah makanan karea kemasan di desa lebih kecil dibandingkan di kota. Akan tetapi, sampah makanan yang dihasilkan dari makanan yang kadaluarsa, makanan yang mudah busuk, lama kelamaan akan menjadi penyebab timbulnya banyak sampah di desa seiring dengan bertambahnya jumlah penduduk di desa. Apalagi jika selama ini sebagian besar desa banyak yang tidak mengelola sampah dengan baik.

\section{Daur ulang sampah makanan dan pengelolaan sampah di desa}

Pemahaman akan daur ulang dan penggunaan ulang pada sampah makanan sangat dibutuhkan. Hasil daur ulang makanan bisa dimanfaatkan untuk memproduksi bahan bakar, pupuk, dan makanan.

Perubahan sosial diperlukan dalam berbagai jenis penggunaan ulang sampah makanan. Upaya untuk mengurangi sampah makanan dan meningkatkan penggunaan by-product sangat dibutuhkan. Ini karena pengurangan sampah makanan menjadi perhatian global. Pengelolaan sampah makanan, terutama pada sistem makanan organic, membutuhkan perencanaan dan pertimbangan teknologi. Proyek yang tepat yang terdiri dari pengendalian parameter kompos dari berbagai tipe daur ulang sampah untuk menjamin sampah potensial negative berhubungan dengan miskinnya pengelolaan sampah.

\section{Pemuda dan perannya dalam transformasi sosial}

Pemuda adalah sumberdaya yang sangat potensial dalam transformasi sosial. Pemuda desa bisa menjadi aktor penggerak perubahan masyarakat desa. Pada kasus pengelolaan sampah, pemuda juga bisa berperan aktif dalam melakukan perubahan sosial di masyarakat desa melalui kegiatan pengelolaan sampah. Beberapa kegiatan perubahan sosial masyarakat jangka panjang yang bisa dilakukan antara lain adalah mengembangkan program kesadaran pada masyarakat, mengembangkan komunikasi masyarakat, merawat peranan positif komunitas dan peran lembaga swadaya masyarakat dan kelompok lain. Gambar 1 adalah hasil penelusuran peranan pemuda dalam kegiatan pengelolaan lingkungan. 


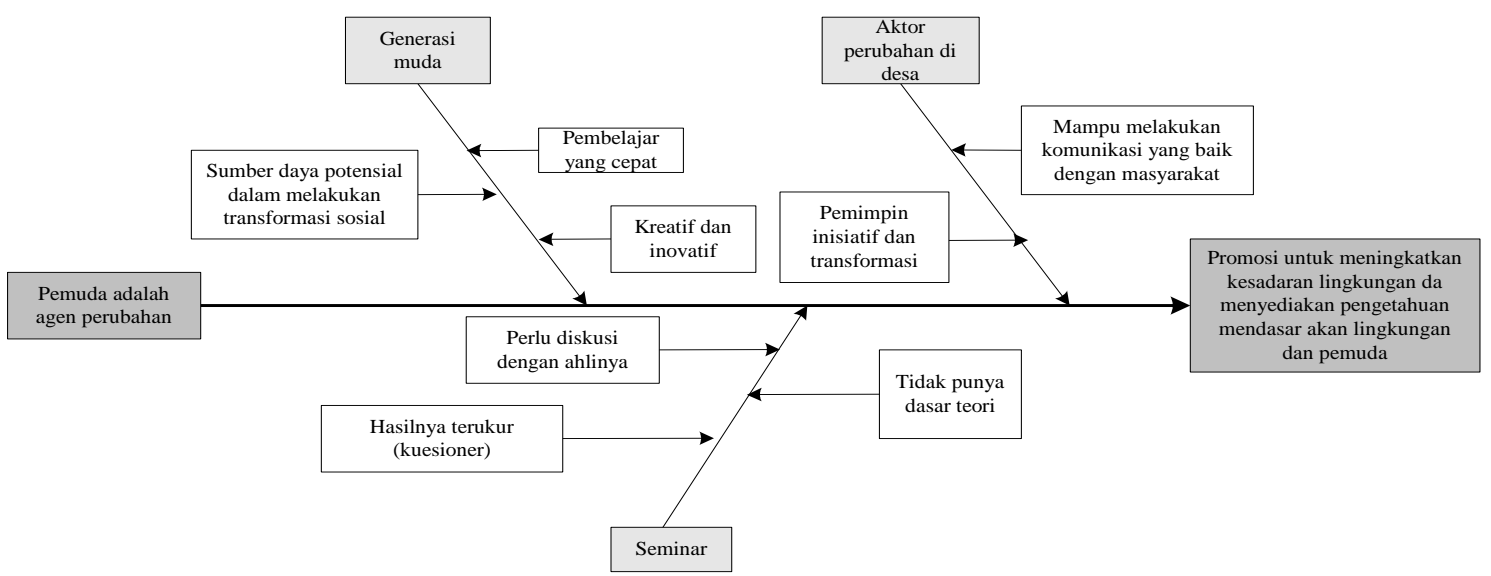

Gambar 1. Pemuda dan peranannya dalam kegiatan pengelolaan lingkungan

\section{METODE DAN ANALISIS KEGIATAN PENGABDIAN KEPADA MASYARAKAT}

Metode kegiatan pengabdian kepada masyarakat yang akan dianalisis dalam artikel ini adalah metode seminar ke pemuda yang aktif dalam kegiatan kepemudaan di desa. Materi yang diberikan dalam seminar adalah mengenalkan jenis-jenis sampah yang dihasilkan oleh rumah tangga, sampah makanan dan bagaiamana mendaur ulangnya. Seminar ini bertujuan untuk meningkatkan pemahaman pemuda desa akan sampah makanan dan bagaiamana mengatasi masalah sampah di desa. Harapan dari kegiatan ini adalah pemuda akan tertarik untuk melakukan kegiatan pengelolaan sampah di desa dan menyebarkan ilmunya ke masyarakat di desa di sekitar mereka tinggal.

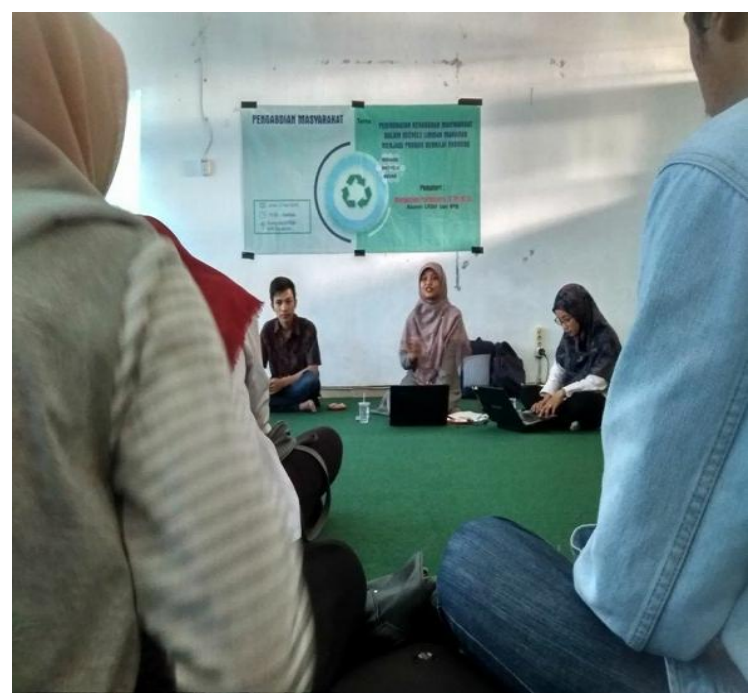

Gambar 2. Pemberian materi kepada pemuda penggerak desa.

Beberapa topik tentang pengelolaan sampah di desa yang disampaikan ke peserta antara lain sampah makanan dan jenis-jenisnya, sampah organik, sampah anorganik, bagaimana mengelola sampah-sampah sesuai deangan jenisnya dan bagaimana mendaur ulah sampah organik dan anorganik. Tiga macam hasil daur ulang sampah makanan yang akan dikenalkan seacara rinci ke peserta adalah daur ulang sisa makanan untuk dijadikan bahan kue, daur ulang sisa dan sampah makanan untuk makanan tumbuhan melaui proses composting, dan daur ulang sampah makanan menjadi makanan binatang.

Daur ulang sisa makanan untuk digunakan sebagai bahan kue dalam pengabdian masyarakat adalah materi daur ulang sisa perasan santan kelapa yang diolah menjadi bahan kue. Materi daur ulang sampah makanan untuk makanan tanaman yang disampaikan dalam pengabdian masyarakat adalah home composting dengan metode Takakura yang telah diterapkan di masyarakat Jepang. Selain itu, materi daur ulang sampah yang dijadikan sebagai makanan binatang juga disampaikan kepada peserta. Kuntungan ekonomi dari melakukan daur ulang juga dijabarkan sehingga peserta mengetahui ada keuntungan ekonomi yang didapat ketika seseorang melakukan daur ulang sampah. Di akhir materi, para pemuda yang menjadi peserta ditanyai kesanggupannya dan keinginannya menyampaikan materi ke masyarakat dan menerapkannya ke masyarakat.

Keefektifan penyelenggaraan pengabdian kepada masyarakat dianalisis melalui kuesioner dengan metode self-evaluation dari partisipan. Enam pertanyaan untuk menanyakan adanya peningkatan pengetahuan peserta terhadap materi dilakukan untuk menilai adanya peningkatan pengetahuan. Pertanyaan tersebut antara lain adalah adanya peningkatan pengetahuan akan sampah domestik, sampah organic, sampah anorganik, reuse sampah domestik, recycle sampah domestikdan recycle sampah makanan. Partisipan akan menilai sendiri 
berapa peningkatan yang dirasakan sesuai dengan apa yang dirasakan setelah mendapatkan materi dari seminar. Empat nilai yang digunakan untuk selfevaluation adalah 0 untuk tidak ada peningkatan, 1 untuk peningkatan kecil, 2 untuk peningkatan sedang, dan 3 untuk peningkatan signifikan. Optimisme untuk melakukan kegiatan pengelolaan sampah di rumah, daur ulang sampah makanan, dan keinginan untuk menyampaikan kembali ke masyarakat mengenai pengelolaan sampah juga ditanyakan ke partisipan. Analisis deskriptif digunakan dalam artikel ini untuk mengevaluasi kegiatan. Ordinal logistic regression logistik ordinal digunakan dalam artikel ini untuk memprediksi keinginan pemuda dalam melakukan pengelolaan sampah di masyarakat dan binary logistic regression digunakan untuk memprediksi keinginan pemuda menyampaikan materi pengelolaan sampah ke masyarakat di sekitar rumah tinggalnya. Persamaan binary logistic regression and ordinal logistic regression megikuti persamaan berikut.

$=\frac{\exp (\alpha+\beta x)}{1+\exp (\alpha+\beta x)}$

\section{HASIL DAN DISKUSI}

Ke-33 peserta pengabdian masyarakat setuju mengisi kuesioner. Dari hasil evaluasi, diperoleh Informasi asal daerah peserta. Dalam artikel ini ditunjukkan dalam Gambar 3. Sebagian besar mereka berusia antara 19 sampai 25 tahun.

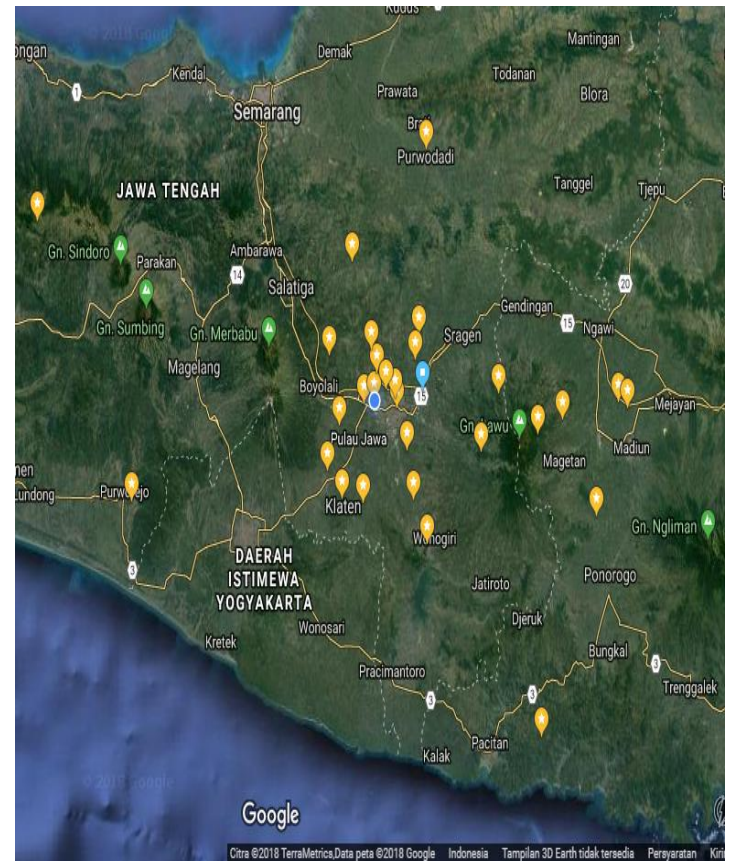

Gambar 3. Asal daerah peserta (bintang dalam balon kuning)
Dari hasil penelusuran melalui kuesioner seperti yang ditunjukkan pada Gambar 4, didapatkan informasi bahwa $71 \%$ dari mereka mengatakan di tempat tinggal mereka tidak terdapat pengelolaan sampah. Sembilan di antaranya mengatakan tidak yakin kalau pemerintah setempat menyediakan pengelolaan sampah di daerah tinggalnya. Sebagian besar dari partisipan tinggal di desa dimana desa merupakan tempat yang rentang kekurangan pengelolaan sampah.

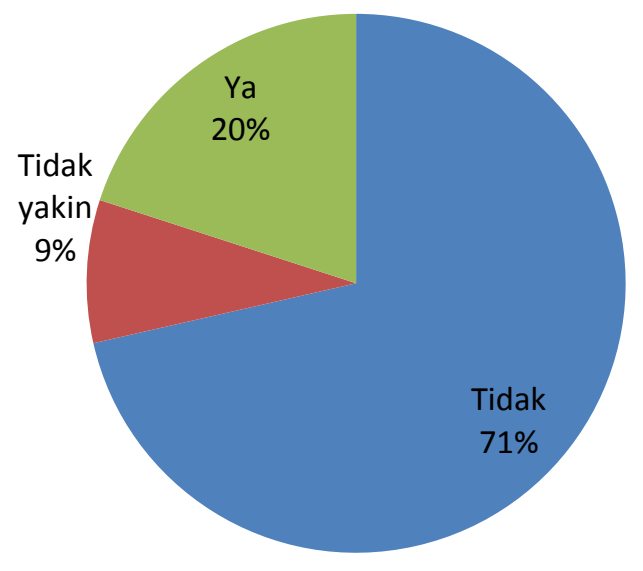

Gambar 4. Ketersediaan pengelolaan sampah di tempat tinggal peserta

Selain itu, dalam artikel ini juga dianalisis peningkatan pengetahuan peserta terhadap pengetahuan akan sampah organik dalam sampah domestik, sampah anorganik dalam sampah domestik, reuse sampah domestik, daur ulang sampah domestik, dan daur ulang sampah makanan. Lima skala yang digunakan adalah dari 0 sampai 4 untuk mengukur tidak ada peningkatan (0), peningkatan kecil (1), peningkatan sedang (2), dan peningkatan signifikan (3). Berdasarkan apa yang dirasakan oleh peserta, mereka merasa semua materi yang diberikan selama seminar meningkatkan pengetahuan mereka (lihat Gambar 5). Tidak ada partisipan yang merasa bahwa seminar tidak meningkatkan pengetahuan mereka akan pengelolaan sampah. Peningkatan pengetahuan terbesar yang mereka rasakan adalah pada materi pengelolaan sampah makanan, materi sampah organik dan anorganik pada sampah makanan. 


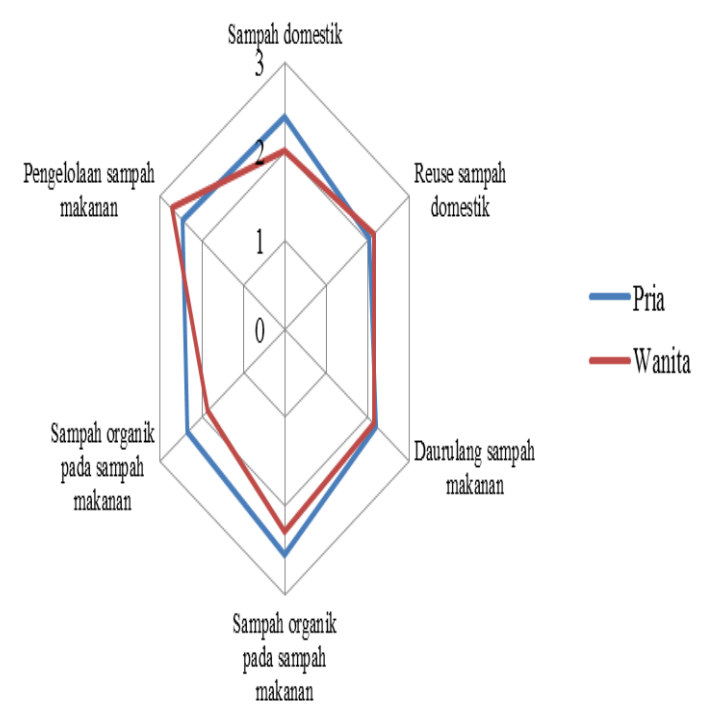

Gambar 5. Peningkatan pemahaman peserta terhadap materi yang diberikan berdasarkan apa yang dirasakan oleh peserta, dimana 0 adalah tidak ada kenaikan, 1 berarti ada kenaikan sedikit, 2 adalah kenaikan agak tinggi, dan 3 berarti ada kenaikan signifikan.

Peningkatan pengetahuan yang dirasakan oleh peserta wanita adalah pada tema sampah makanan anorganik. Akan tetapi, pada tema ini peserta pria merasakan mengalami kenaikan pengetahuan yang signifikan. Daurulang sapah anorganik sebenarnya sudah umum di masyarakat. Namun, secara umum, pengetahuan mengenai daur ulang sampah diberikan kepada kaum wanita atau ibu-ibu rumah tangga. Selain itu, urusan rumah tangga, termasuk di dalamnya adalah membersihkan rumah dan memasak, di masyarakat kita pada umumnya diserahkan pada kaum wanita. Pengetahuan akan sampah anorganik seperti kantong plastic, botol plastic, kaleng, botol kaca dan kertas merupakan sumber sampah yang sangat umum dipahami oleh masyarakat. Oleh karenanya, kaum wanita dalam program pengabdian masyarakat ini merasa peningkatan pengetahuan mereka akan sampah anorganik adalah kecil karena sebelumnya sudah mendapat Informasi dan bahkan sudah mengenalnya dalam kehidupan sehari-hari. Berbeda dengan peserta pria yang masih muda. Kemungkinan mereka jarang melakukan kegiatan rumah tangga sehingga merasa mendapat tambahan pengetahuan akan sampah anorganik setelah seminar dilakukan.

Dalam kegiatan pengabdian masyarakat ini, perempuan merasa mendapat penambahan pengetahuan tertinggi pada matera pengelolaan sampah makanan. Kegiatan menyiapkan makanan sering kali diidentikkan dengan kegiatan perempuan. Sebagian besar peserta telah mengetahui masalah pengelolaan sampah menjadi kompor. Namun, pengelolaan sisa makanan yang dapat diolah menjadi bahan kue dan dapat dioleh menjadi makanan binatang adalah materi relatif baru bagi mereka.

Di akhir seminar, sebagian peserta memiliki keinginan untuk melakukan daur ulang sampah makanan. Hasilnya dapat dilihat pada Gambar 6. Sebagian besar dari mereka juga punya keinginan untuk menyebarkan kepada masyarakat di sekitar tempat tinggal mereka pengetahuan tentang pengelolaan sampah. Namun, meskipun mereka punya keinginan untuk menyebarkan pengetahuan, beberapa di antara mereka tidak memiliki optimisme yang tinggi untuk melakukan daur ulang sampah.

Optimisme

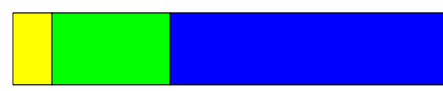

Minat mendaurulang sampah makanan

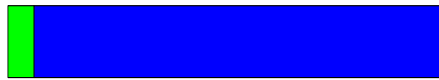

Minat menyebarkan pengetahuan pengelolaan sampah

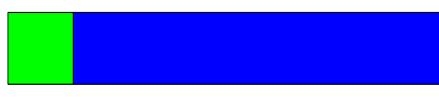

Rendah $\square$ Moderat $\square$ Tinggi

Gambar 6. Optimisme melakukan pengelolaan sampah, minat mendaur ulang, dan minat menyebarkan pengetahuan

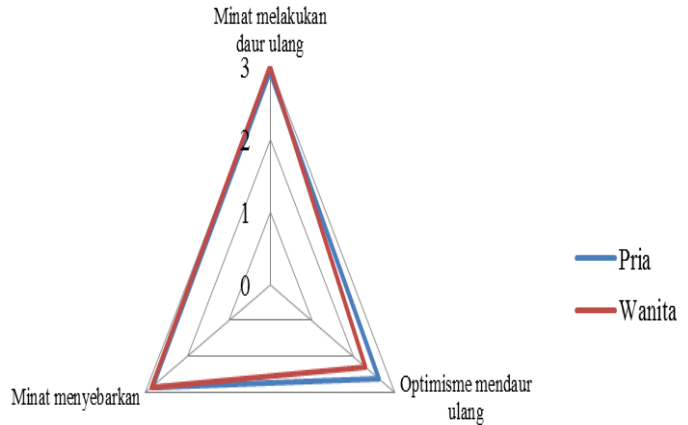

Figure 6. Optimisme, minat melakukan daur ulang sampah makanan dan minat menyebarkannya berdasarkan gender

Dari Gambar 6, peserta pria lebih optimis melakukan kegiatan daur ulang dibandigkan peserta perempuan. Dari peserta yang ada, hamper semua peserta pria merupakan ketua penggerak kegiatan kepemudaan di kampong halamannya. Mereka punya power untuk mengubah masyarakat dalam melakukan aktifitas pengelolaan sampah domestik. Hasil dari studi meta analisis yang dilakukan oleh Miafodzyeva \& Brandt (2013) menunjukkan bahwa 
sebagian besar dari artikel yang ditelitinya membuktikan bahwa gender mempunyai hubungan yang positif dengan kegiatan mendaur ulang dimana wanita lebih peduli dalam melakukan kegiatan daur ulang. Dalam artikel ini tidak dilakukan pengamatan perilaku peserta. Tetapi dilakukan studi minat peserta untuk melakukan kegiatan daur ulang. Hasilnya, peserta wanita lebih berminat melakukan kegiatan daur ulang daripada peserta pria. Ini menjadi indikasi awal bahwa wanita lebih peduli terhadap kegiatan daur ulang daripada pria.

Data dari studi ini juga membuktikan bahwa model bahwa peningkatan pengetahuan akan melakukan daur ulang mempengaruhi optimisme peserta dalam melakukan kegiatan pengelolaan sampah. Ini bisa dilihat dari model ordinal logistic regression pada Tabel 2. Dari model diperoleh informasi bahwa peningkatan pengetahuan akan daur ulang mempengaruhi optimisme moderat, tetapi tidak berpengaruh ke peserta yang optimismenya rendah.

Tabel 2. Ordinal logistic regression model optimisme melakukan kegiatan daur ulang dan peningkatan pengetahuan mendur ulang sampah makanan.

\begin{tabular}{|c|c|c|c|c|c|}
\hline \multirow{2}{*}{$\begin{array}{c}\text { Param } \\
\text { eter }\end{array}$} & $\begin{array}{c}\text { Estimasi } \\
\text { paramet } \\
\text { er }(p- \\
\text { value })\end{array}$ & $\begin{array}{c}\text { Od } \\
\text { rati } \\
o\end{array}$ & $\begin{array}{c}G^{2}(p- \\
\text { value })\end{array}$ & $\begin{array}{c}\chi^{2} \text { Pears } \\
\text { on }(p- \\
\text { value })\end{array}$ & $\begin{array}{c}\chi^{2} \text { Devi } \\
\text { ance } \\
(p- \\
\text { value })\end{array}$ \\
\hline$\alpha(1)$ & $\begin{array}{c}1.13(0.4 \\
29)\end{array}$ & & $\begin{array}{c}7.018(0.0 \\
08)\end{array}$ & $\begin{array}{c}3.95(0.2 \\
67)\end{array}$ & $\begin{array}{c}4.39(0 . \\
222)\end{array}$ \\
\hline$\alpha(2)$ & $\begin{array}{c}3.23(0.0 \\
32)\end{array}$ & & & & \\
\hline$\beta_{\text {KIR }}$ & - & 0.1 & & & \\
& $1.67(0.0$ & 9 & & & \\
\hline
\end{tabular}

Selain itu, artikel ini juga mengidentifikasi hubungan antara peningkatan pengetahuan terhadap minat menyebarkannya. Peningkatan pengetahuan adalah kenaikan pengetahuan dalam studi ini dilihat dari peningkatan pengetahuan akan sampah domestik, reuse dan recycle. Dari Gambar 6 terdapat dua respons jawaban keinginan untuk menyebarkan pengetahuan yaitu minat moderat dan minat tinggi. Di sini, binary logistic regression digunakan untuk membuat modelnya.

Hasil studi membuktikan bahwa peningkatan pengetahuan mempengaruhi minat pemuda untuk menyebarkan pengetahuannya ke masyarakat di sekitar tempat tinggalnya. Model dari binary logistic regression adalah:

$$
\pi(x)=\frac{\exp (-6.81+1.52 x)}{1+\exp (-6.81+1.52 x)}
$$

Goodness of fit dari model tersebut ditunjukkan pada Tabel 2. Rendahnya $p$-value dari $G^{2}$ dan tingginya $p$-value dari $\chi^{2}$ yang mendekati nilai 1 berarti tidak ada argument yang mendukung bahwa model tidak cukup untuk mengatakan ada hubungan antara peningkatan pengetahuan dan minat untuk menyebarkan pengetahuannya tentang pengelolaan sampah makanan. Odd ratio dari model adalah $\exp (1.52)=4.61$. Ini berarti peningkatan pengetahuan satu satuan akan meningkatkan 4.61 kali minat menyebarkan pengetahuan mengelola limbang makanan ke masyarakat sekitar.

Tabel 2: Binary logistic goodness of fit untuk minat menyebarkan pengetahuan $(y)$ dan peningkatan pengetahuan $\left(x_{1}\right)$

\begin{tabular}{|c|c|c|}
\hline \multicolumn{3}{|c|}{ Goodness of fit } \\
\hline $\begin{array}{c}G^{2}(p- \\
\text { value })\end{array}$ & $\begin{array}{c}\chi^{2} \text { Pearson }(p- \\
\text { value })\end{array}$ & $\begin{array}{c}\chi^{2} \text { Deviance }(p- \\
\text { value })\end{array}$ \\
\hline $9.32(0.002)$ & $0.18(0.996)$ & $0.28(0.991)$ \\
\hline
\end{tabular}

Studi dari Poškus \& Žukauskienė (2017) membuktikan bahwa perceived behavioural control yang dalam hal ini bisa dijadikan sebagai indikator keoptimisan seseorang mempengaruhi minat anakanak untuk melakukan daur ulang. Hasil yang sama pada kasus pemuda juga ditemukan oleh Mahmud \& Osman (2010). Penelitian lain mengatakan pengetahuan saja masih belum cukup untuk bisa mengubah perilaku seseoarng, akan tetap pengetahuan itu sangat diperlukan oleh pemuda (Daniel et al., 2018). Namun, ada penelitian lainnya membuktikan bahwa memberi pengetahuan daur ulang ke masyarakat dan meminta mereka untuk melakukan kegiatan daur ulang adalah salah satu cara yang sangat efektif untuk mengubah perilaku masyarakat dalam melakukan daur ulang (Dai et al., 2015).

\section{KESIMPULAN}

Intervensi sosial ke pemuda bisa dianggap sebagai cara yang efektif dalam mengubah masyarakat. Pemberian seminar tanpa dipungut biaya yang menyampaikan materi-materi daur ulang sampah mampu meningkatkan pengetahuan pemuda dalam hal duar ulang sampah. Kegiatan ini juga mampu merangsang minat mereka untuk melakukan kegiatan daur ulang di tempat tinggalnya karena kegiatan daur ulang mampu memberi manfaat ekonomi selain dapat mencegah kerusakan lingkungan. Akan tetapi, minat yang tinggi tidak berarti membuat orang optimis mampu melakukan. Beberapa faktor penghambat level optimisme melakukan daur ulang di masyarakat yang akan dihadapi oleh mereka ketika menerapkan daur ulang 
di masyarakat. Oleh karena itu, kegiatan tambahan seperti pendampingan secara kontinyu dalam pelaksanaan di masyarakat juga diperlukan. Akan tetapi, dukungan secara institusi sangat diperlukan karena dukungan ini lebih mampu menggerakkan perubahan perilaku masyarakat (Refsgaard \& Magnussen, 2010).

\section{UCAPAN TERIMAKASIH}

Kegiatan Pengadian Kepada Masyarakat tahun 2018 di Fakultas Ekonomi dan Bisnis Islam Institut Agama Islam Negeri Surakarta dari anggaran BOPTN IAIN Surakarta 2018.

\section{DAFTAR PUSATAKA}

[1] Abdelradi, F. (2018). Food waste behaviour at the household level: A conceptual framework. Waste Management, $\quad 71, \quad 485-493$ http://doi.org/10.1016/j.wasman.2017.10.001

[2] Bekin, C. (2007). Beyond Recycling: Commons Friendly' Waste Reduction at New Consumption Communities, 44(0), 1-42.

[3] Dai, Y. C., Gordon, M. P. R., Ye, J. Y., Xu, D. Y., Lin, Z. Y., Robinson, N. K. L., ... Harder, M. K. (2015). Why doorstepping can increase household waste recycling. Resources, Conservation and Recycling, 102 , 9-19. http://doi.org/10.1016/j.resconrec.2015.06.004

[4] Daniel, F., Ioannidi, E., Sun, Y., Jape, V. W., Bawono, W. R., Zhang, S., \& Perez-cueto, F. J. A. (2018). Consumers with high education levels belonging to the millennial generation from Denmark, Greece, Indonesia and Taiwan differ in the level of knowledge on food waste. International Journal of Gastronomy and Food Science, 11, 49-54. http://doi.org/10.1016/j.ijgfs.2017.11.005

[5] Dorward, L. J. (2012). Where are the best opportunities for reducing greenhouse gas emissions in the food system (including the food chain)? A comment. Food Policy, 37(4), 463-466. http://doi.org/10.1016/j.foodpol.2012.04.006

[6] FAO. (2012). The role of producer organizations in reducing food loss and waste.

[7] Franchetti, M. (2013). Economic and environmental analysis of four different configurations of anaerobic digestion for food waste to energy conversion using LCA for: A food service provider case study. Journal of Environmental Management, 123, 42-48. http://doi.org/10.1016/j.jenvman.2013.03.003

[8] Gustavsson, J., Cederberg, C., Sonesson, U., \& Emanuelsson, A. (2013). The methodology of the FAO study: "Global Food Losses and Food Waste - extent, causes and prevention " - FAO , 2011 By SIK - The Swedish Institute for Food and Biotechnology.

[9] Han, S., \& Shin, H. (2004). Biohydrogen production by anaerobic fermentation of food waste, $29,569-577$. http://doi.org/10.1016/j.ijhydene.2003.09.001

[10] Iacovidou, E., Ohandja, D., Gronow, J., \& Voulvoulis, N. (2012). The Household Use of Food Waste Disposal Units as a Waste Management Option: A Review. Critical Reviews in Environmental Science and Technology, 14, 1485-1508. http://doi.org/10.1080/10643389.2011.556897
[11] Irani, Z., Sharif, A. M., Lee, H., Aktas, E., \& Sahuda, S. (2017). Managing food security through food waste and loss: Small data to. Computers and Operations Research, 0 $1-17$. http://doi.org/10.1016/j.cor.2017.10.007

[12] Lang, T., \& Rayner, G. (2012). Waste Lands? In N. Doron (Ed.), Revaluing Food. London: Fabian Society.

[13] Lebersorger, S., \& Schneider, F. (2011). Discussion on the methodology for determining food waste in household waste composition studies. Waste Management, 31(9-10), 1924-1933. http://doi.org/10.1016/j.wasman.2011.05.023

[14] Lundie, S., \& Peters, G. M. (2005). Life cycle assessment of food waste management options. Journal of Cleaner Production, 13, 275-286. http://doi.org/10.1016/j.jclepro.2004.02.020

[15] Mahmud, S. N. D., \& Osman, K. (2010). The determinants of recycling intention behavior among the Malaysian school students: An application of theory of planned behaviour. Procedia Social and Behavioural Sciences, 9, 119-124. http://doi.org/10.1016/j.sbspro.2010.12.123

[16] Mattar, L., Abiad, M. G., Chalak, A., Diab, M., \& Hassan, H. (2018). Attitudes and Behaviors Shaping Household Food Waste Generation: Lessons from Lebanon. Journal of Cleaner Production, 198, 12191223. http://doi.org/10.1016/j.jclepro.2018.07.085

[17] Miafodzyeva, S., \& Brandt, N. (2013). Recycling Behaviour Among Householders: Synthesizing Determinants Via a Meta-analysis. Waste and Biomass, 4(2), 221-235. http://doi.org/10.1007/s12649-012-9144-4

[18] Monier, V., Mudgal, S., \& Escalon, V. (2010). Preparatory study on food waste across EU 27 (Vol. 27). Paris

[19] Poškus, M. S., \& Žukauskienė, R. (2017). Predicting adolescents' recycling behavior among different big five personality types. Journal of Environmental Psychology, 54, 57-64. http://doi.org/10.1016/j.jenvp.2017.10.003

[20] Refsgaard, K., \& Magnussen, K. (2010). Household behaviour and attitudes with respect to recycling food waste e experiences from focus groups. Journal of Environmental Management, 90(2), 760-771. http://doi.org/10.1016/j.jenvman.2008.01.018

[21] Reutter, B., Lant, P. A., \& Lane, J. L. (2017). The challenge of characterising food waste at a national level - An Australian example. Environmental Science and Policy, 78(December 2016), 157-166. http://doi.org/10.1016/j.envsci.2017.09.014

[22] The Economist. (2016). Fixing Food: Towards a more sustainable food system. Parma.

[23] USEPA. (2012). Food Waste. Retrieved from http://www.epa.gov/osw/conserve/materials/organics/f ood/

[24] Xu, F., Li, Y., Ge, X., Yang, L., \& Li, Y. (2018). Anaerobic digestion of food waste - challenges and opportunities. Bioresource Technology, 247, 10471058. http://doi.org/10.1016/j.biortech.2017.09.020 